\title{
Prevalence of histological findings of human papillomavirus (HPV) in oral and oropharyngeal squamous cell carcinoma biopsies: preliminary study
}

\section{Sandra Doria Xavier', Ivo Bussoloti Filbo', Carmem Lúcia Penteado Lancellotti ${ }^{3}$}

Key words: carcinoma, papillomavirus, mouth, oropharynx.

\section{Summary}

\begin{abstract}
$\mathrm{H}$ uman papillomavirus (HPV) is considered to be an etiologic agent of cervical cancer and, recently its relation to oral and oropharyngeal cancer has also been investigated. Oral squamous cell carcinoma (SCC) represents $90 \%$ of all malignant tumors that affect the oral cavity. The prevalence of HPV in patients with SCC ranges from 0 to $100 \%$. The most known viral cytopathic effect is koilocytosis, considered to be a major characteristic of HPV infection. Aim: The aim of this study was to verify the prevalence of some peculiar characteristics of HPV - koilocytosis - in oral and oropharyngeal SCC. Study design: transversal cohort. Material and method: Twenty slides with oral and/or oropharyngeal SCC were examined under microscopy. Results: in 15 of them, koilocytosis was found, amounting to $75 \%$. Although we know that polymerase chain reaction (PCR) is the method with the best sensitivity for HPV detection, we began this research looking for koilocytosis, which is highly suggestive of HPV infection. Conclusion: This study is a trial project and we will continue this research with PCR measures to confirm this high prevalence of HPV infection in oral and oropharyngeal SCC.
\end{abstract}




\section{INTRODUCTION}

The Human papillomavirus virus (HPV) is a small sized virus of intranuclear replication with diameter of approximately $50 \mathrm{~nm}{ }^{1}$. It may infect mucosa and skin surfaces in almost all vertebrate species ${ }^{2}$. Seventy types of HPV ${ }^{3}$ have been identified so far and were classified according to its distribution on nucleic acids in the viral genome. The subtypes found in the oral cavity were $1,2,4$, $6,11,13,16,18,30,31,32$ and $57^{4}$.

Comprehensive research studies related some subtypes of HPV to malignant and pre-malignant lesions of cervix, vulva, penis, conjunctive and upper digestive tract and airways 5 . HPV is universally accepted as an etiologic agent of cervical cancer, and its relation to oral and oropharynx cancer has recently been investigated. The most popular viral cytopathic effect of HPV is koilocytosis and is considered a "major criterion" in HPV infection from the pathophysiological point of view. Koilocytotic atypia consists in nuclear atypia and perinuclear vacuolization. ${ }^{6}$

Today, there are molecular biology methods to study HPV such as in situ hybridization (ISH), hybrid capture and PCR that provide not only increased sensitivity in diagnosis, but also the typing of HPV, but costs of such exams are higher if compared against the detection of koilocytosis hematoxylin-eosin stained slides.

\section{HPV and Oral Spinocellular Carcinoma (OSC)}

Oral squamous cell carcinoma is also known as epidermoid or oral spinocellular carcinoma (OSC) and accounts for $90 \%$ of all malignant tumors that affect the oral cavity ${ }^{7}$. The most common factors associated with oral cancer development are smoking, alcohol, syphilis, nutritional deficiencies, sunray exposure, trauma, poor hygiene and irritation of the teeth or dental prosthetics ${ }^{8}$. In addition to those factors, the viruses have been investigated as likely carcinogenic agents. Sÿrjanen et al. ${ }^{9}$ suggested HPV may play a role in oral cancer if associated with cell abnormalities found in malignant and pre-malignant lesions of the mouth similar to those that occurred in cervical cancer. The HPV infection is identified as the most common cause of $95 \%$ of cervical carcinomas and a large rate of other genital carcinomas ${ }^{10}$.

Tobacco and alcohol abuse are well established risk factors for oral cancer, but a small rate (15-20\%) of the patients do not have any past history of smoking or alcohol addiction suggesting the presence of other risk factors ${ }^{11}$ such as HPV, but its role has not been clearly defined yet. An intriguing finding is the rate of approximately $40 \%$ reduction in death risk in patients with positive HPV tumors.

HPV 16 is the most common type of virus associated with oral and cervical cancer ${ }^{12,13}$ whereas types 6 and 11 are more commonly found in benign and pre-malignant lesions and rarely found in neoplastic head and neck lesions ${ }^{14}$

The importance of HPV infection in oral carcinogenesis is supported by the ability of high risk HPV to immortalize oral keratinocytes in vitro ${ }^{15}$.

\section{OBJECTIVE}

The objective of this study is to determine the prevalence of suggestive findings of HPV, koilocytosis in OSC of the oral cavity and oropharynx through histological analysis of such lesions.

\section{MATERIAL AND METHOD}

Twenty patients diagnosed with OSC of the oral cavity and oropharynx were examined with optical microscopy to investigate suggestive signs of HPV infection in hematoxylineosin stained slides.

Concomitantly, the records of the 20 cases were investigated as shown in Table 1.1.

\section{RESULTS}

Seventy-five percent of the cases (15/20) presented koilocytosis, and were identified as positive cases of koilocytosis (C+).

The survey in patients' records showed that 19 patients were male and 1 patient was female, ages ranging from 42 to 86 years (mean age $=58.9$ ). Fifteen patients were White, three were Brown and two were Black. The group of $\mathrm{C}+$ patients had ages that ranged from 47 to 80 years (mean age $=57.9$ ). The group of $\mathrm{C}$ patients had ages that ranged from 42 to 86 years (mean age $=61.8)$

Eleven patients were smokers (55\%) and six were alcohol abusers (30\%), with 6 patients (30\%) - 5 C+ and 1 patient $\mathrm{C}$ - that did not have any smoking or alcohol history in their records. The group of $\mathrm{C}+$ patients had $60 \%$ of smokers and $40 \%$ of alcoholics, whereas the group C- had $40 \%$ smokers and did not have any alcoholic patient as shown in Table 2.

The tumor location varied. Most occurred in the palate (35\%) - 20\% in the soft palate and 15\% in the hard palate - followed by the oral cavity floor (25\%), oropharynx (20\%), tongue (10\%), gums (5\%) and jugal mucosa (5\%). In the $\mathrm{C}+$ group, the most common sites were palate and oral cavity floor, both with $27 \%$ rate, whereas in the group $\mathrm{C}$ - the most common site involved was the palate region (60\%)

In regards to the clinical aspect upon diagnosis, most of the patients had ulcerated infiltrating lesion (60\%) and in advanced staging - T4 (50\%), in 7 patients (35\%) - $5 \mathrm{C}+$ and 
2 C- - did not have any report of clinical staging in their records. In the $\mathrm{C}+$ group, $66 \%$ of the patients had ulcerated infiltrating lesion and 54\% were in advanced staging, whereas in the C- group, $40 \%$ of the patients had ulcerated infiltrating lesions and $40 \%$ were in advanced staging.

\section{DISCUSSION}

In this study, koilocytosis was found in 15 out of the 20 slides investigated, accounting for $75 \%$ of the cases.

Koilocytosis first described by Leopoldo Koss et al. in $1956^{16}$, consists in a picnotic nuclei surrounded by extensive clear halos with a volume generally higher than the cytoplasm if observed in slides under optical microscope, as seen in Figure 1.

According to some authors ${ }^{17,18}$, the koilocytosis is a pathognomonic sign of HPV infection serving as a foundation for molecular biology studies.

Some papers in the literature report that HPV frequency in oral carcinoma ranges from 0 to $100 \% 0^{13,19}$ whereas other investigators report it ranges from 18 to $100 \%{ }^{12,14}$. The mean frequency of $25 \%$ was estimated by Garlick $^{20}$ in his review about the topic. As it can be seen, the variability is extreme and may be a consequence of different sample sizes or methods used with variable sensitivity and specificity.

Herrero et al. ${ }^{21}$ demonstrated HPV DNA in 3.9\% of 766 cancer biopsies of the oral cavity and in $18.3 \%$ of the 142 biopsies of oropharynx cancer, through the PCR study. Klussmann et al. ${ }^{22}$ found $18 \%$ of HPV DNA in cancer biopsies of the oral cavity, $8 \%$ in nasopharynx cancer, 25\% in hypopharynx cancer and 45\% in oropharynx cancer and particularly in tonsil carcinomas (58\%). Ritchie et al. ${ }^{23}$ detected HPV in $21 \%$ of the oral cavity and oropharynx cancers, with 83\% of HPV -16 . Ha et al. ${ }^{24}$ reported $0.98 \%$ of HPV DNA in pre-malignant lesions and only $2.9 \%$ in malignant lesions of the oral cavity.

Niv et al. ${ }^{25}$ conducted a study to investigate HPV presence in oral cavity carcinoma and found a positive rate of $17.3 \%$; in all cases the tumor was located in the anterior tonsillar pillar. In other studies, the most common tumor sites where they found HPV were jugal and palate mucosa $(40-50 \%)^{26}$. In this study, the most common locations were palate and oral cavity floor, both with $27 \%$ prevalence.

Positive HPV carcinoma seem to be a distinctive entity (involve more basal cells and have lower inflammatory component), with distinct biology (less p 53 mutation), distinct risk factors (less association with tobacco and alcohol and a different clinical outcome - higher survival rate) ${ }^{11}$. Conversely, this study did not show lower association with tobacco and alcoholism, but higher percentage of alcoholic and smokers in group $\mathrm{C}+$.

Cruz et al. ${ }^{27}$ observed that patients under 60 years of age with oral carcinoma presented eight times higher risk of being infected by HPV than people older than 60 years. In this study, men presented increased HPV positive responses

Table 1. List of patients with oral or oropharynx OSC.

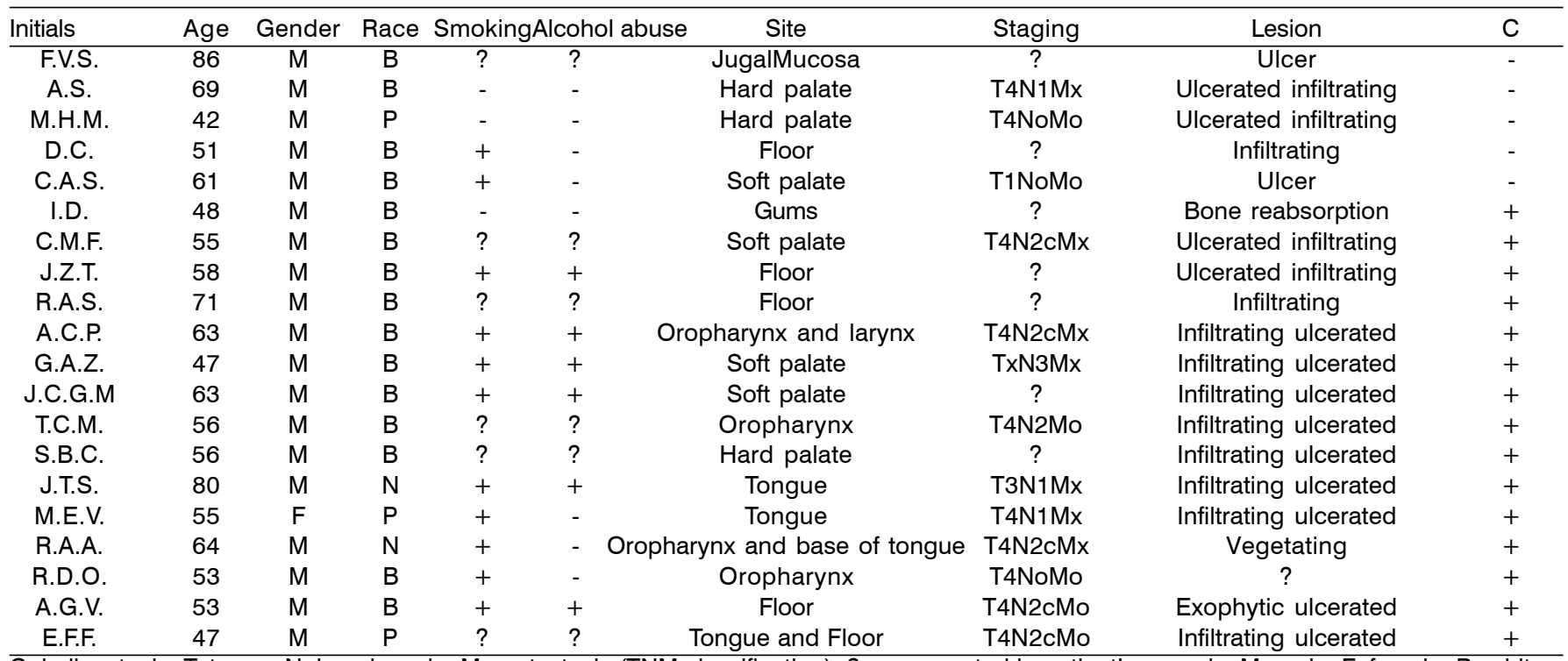

C: koilocytosis; T: tumor, N: lymph node, M: metastasis (TNM classification); ?:non-reported in patient's records; M: male, F: female; B: white,

P: brown, N: black; +: present, -: absent. 
than women, but an association between HPV infection and tumor location, clinical staging in diagnosis or smoking, and alcoholism could not be found. This survey did not show any significant difference of age range between groups $\mathrm{C}+$ and C-.

Klussmann ET al. ${ }^{28}$ reported a statistically significant difference between HPV prevalence in oropharynx tumor (45\%), especially in palatine tonsils (58\%) against the other sites of the oral cavity ( 7 to $25 \%$ ).

Some authors ${ }^{11,28}$ believe that positive HPV palatine tonsil carcinomas constitute an independent tumor entity. Klussmann et al. ${ }^{28}$ found out that these patients present statistically lower exposure level to known risk factors such as smoking and alcoholism. They also found a statistically significant correlation between HPV and low level of tumor differentiation, contrary to the previous findings the authors mentioned.

Miller and Johnstone ${ }^{29}$ concluded in their metaanalysis from 1982-1997 that HPV is an independent risk factor and extremely important in OSC, and their results indicated that HPV detection is twice to three times more common in oral pre-malignant lesions and 4 to 7 times

Table 2. Smoking and alcoholism in patients with positive and negative koilocytosis.

\begin{tabular}{lcc}
\hline & $C+(n=15)$ & $C-(n=5)$ \\
\hline Smoking $(n=11)$ & $60 \%$ & $40 \%$ \\
Alcoholism $(n=6)$ & $40 \%$ & $0 \%$ \\
+ Common Site & Palate $(27 \%)$ & Palate $(60 \%)$ \\
& and floor $(27 \%)$ & \\
\hline C+: koilocytosis & &
\end{tabular}

$\overline{\mathrm{C}+\text { : koilocytosis }}$

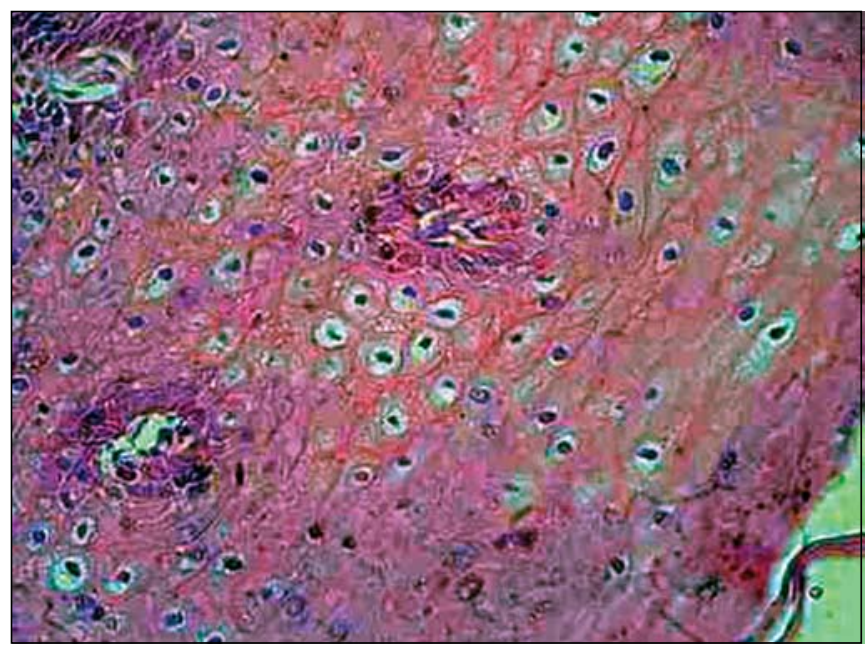

Figure 1. Hematoxylin-eosin stained slides showing koilocytosis: cells with picnotic halo, surrounded by clear outside halos with volume generally higher than that of the cytoplasm. more common in OSC if compared against normal oral mucosa.

Brandwein et al..$^{30}$ did not find any statistical association between HPV and TNM staging and also between clinical and differentiation aspects of the tumor. In this study, there were no statistically significant differences found between negative and positive HPV regarding its disease-free interval and survival time.

Although we know that PCR is the best current method to detect HPV this study began by investigating koilocytosis in hematoxylin-eosin stained slides, which is highly suggestive of HPV infection. This study is part of a pilot project that will be followed up by PCR tests to be performed in all slides previously examined to confirm the high prevalence of HPV infection in oral OSC. The histological analysis by itself may suggest the presence of HPV and is a screening method of HPV-related lesions. It is quite a useful method in centers in which sophisticated molecular biology survey methods are unavailable.

\section{CONCLUSION}

Careful anatomic pathological survey of OSC of oral cavity and oropharynx showed high prevalence of koilocytosis - 75\% -, indicating a likely high HPV prevalence in this type of tumors.

\section{REFERENCES}

1. Sarruf MBJM, Dias EP. Avaliação citopatológica da cavidade bucal em pacientes portadores de infecção genital pelo papilomavírus humano (HPV). J Bras Doenças Sex Trans 1997; 9(2): 4-18.

2. Howley PM, Schlegel R. The human papillomaviruses. An overview. (Review). Am J Med 1988; 85(2A): 155-8.

3. Oliveira LHS. Virologia Humana. Rio de Janeiro: Cultura Médica; 1994. p 311.

4. Kellokoski JK, Syrjanen SM, Syrjanem KJY, Kiloski M. Oral mucosal changes in women with genital HPV infection. J Oral Pathol Med 1990; 19: 142-8.

5. Pfister H, Fuchs PG, Volcker HE. Human papillomavirus DNA in conjuntival papilloma. Graefes Arch Clin Exp Ophthamol 1985; 223: $164-7$.

6. Cotran RS, Kumar V, Robbins SL, Schoen FJ. Patologia Estrutural e Funcional. 5o ed. Rio de Janeiro: Guanabara- Koogan; 1996. p. 937

7. Neville BW, Damm DD, Allen CM, Bouquot JE. Patologia Oral e Maxilofacial. 1으. Rio de Janeiro: Guanabara- Koogan; 1998. p. 705.

8. Shafer WG, Hine MK, Levy BM. Tratado de Patologia Bucal. $2^{\circ}$ ed. Rio de Janeiro: Interamericana; 1985.

9. Syrjanen K, Gissman L, Koss K. Papillomaviruses and human disease. Berlin/ Heidelberg/ New York: Springer; 1987. p. 104, 37.

10. Rosenberg SK, Greenberg MD, Reid R. Sexually transmitted papilloma viral infection in men. Obstet Gynecol Clin North Am 1987; 14: 495-512.

11. Gillison ML, Koch WM, Capone RB et al. Evidence for a causal association between human papillomavirus and a subset of head and neck cancers. JNCI 2000; 92(9): 709-20.

12. Yeudall WA. Human papillomavirus and oral neoplasia. Oral Oncol Eur J Cancer 1992; 28B: 61-6. 
13. Woods K, Shillitoe E, Spitz M, Schantz S, Adler-Stortz K. Analysis of human papillomavirus DNA in oral squamous cell carcinomas. J Oral Pathol Med 1993; 22: 101-8.

14. Snijders PJ, Scholes AG, Hart CA, Jones AS, Vaughan ED, Woolgar JA et al. Prevalence of mucosotropic human papillomaviruses in squamous-cell carcinomas of the head and neck. Int J Cancer 1996; 66: 464-9.

15. Sugerman PB, Shillitoe EJ. The high risk human papillomaviruses and oral cancer: evidence for and against a causal relationship. Oral Dis 1997; 3: 130-47.

16. Koss LG, Durfee GR. Unusual patterns of squamous epithelium of the uterine cervix: cytologic and pathologic study of koilocytic atypia. Ann N Y Acad Sci 1956; 63: 1245-61.

17. Syrjänen K, Syrjänen S, Lamberg M, Pyrhönen S, Nuutinen J. Morphological and immunohistochemical evidence suggesting human papillomavirus (HPV) involvement in oral squamous cell carcinogenesis. Int J Oral Surg 1983; 12: 418-24.

18. Premoli-de-Percoco G, Galindo I, Ramirez JL, Perrone M, Rivera H. Detection of human papillomavirus-related oral verruca vulgaris among Venezuelans. J Oral Pathol Med 1993; 22: 113-6.

19. Dekmezian RH, Batsakis JG, Goepfert H. In situ hybridization of papillomavirus DNA in head and neck squamous cell carcinomas. Arch. Otolaryngol. Head Neck Surg 1987; 113: 819-21.

20. Garlick JA, Taichman IB. Human papillomavirus infection of the oral mucosa. Am J Dermatopathol 1991; 13: 386-95.

21. Herrero $\mathrm{R}$ et al. Human papillomavirus and oral cancer: the International Agency for Research on Cancer multicenter study. J Natl Cancer Inst 2003; 95(23): 1772-83.

22. Klussmann JP, Weissenborn SJ, Wieland U, Dries V, Eckel HE, Pfister HJ, Fuchs PG. Human pappilomavirus-positive tonsillar carcinomas: a different tumor entity? Med Microbiol Immunol 2003 (Berl); 192(3): 129-32.
23. Ritchie JM, Smith EM, Summersgill KF, Hoffman HT, Wang D, Klussmann JP, Turek LP, Haugen TH. Human papillomavirus infection as a prognostic factor in carcinomas of the oral cavity and oropharynx. Int $\mathrm{J}$ Cancer 2003; 104(3): 336-44.

24. Ha PK, Pai SI, Westra WH, Gillison ML, Tong BC, Sidransky D, Califano JA. Real-time quantitative PCR demonstrates low prevalence of human papillomavirustype 16 in premalignant and malignant lesions of the oral cavity. Clin Cancer Res 2002; 8(5): 1203-9.

25. Niv A, Sion-Vardi N, Gatot A, Nash M, Fliss DM. Identification and typing of human papillomavirus (HPV) in squamous cell carcinoma of the oral cavity and oropharynx. J Laryngol Otol 2000; 114: 41-6.

26. Shindoh M, Chiba I, Yasuda M. et al. Detection of human papillomavirus DNA sequences in oral squamous cell carcinomas and their relation to p54 and proliferating cell nuclear antigen expression. Cancer 1995; 76: 1513-21.

27. Cruz IBF, Snijders PJF, Steenbergen RDM, et al. Age- dependence of human papillomavirus DNA presence in oral squamous cell carcinomas. Oral Oncol Eur J Cancer 1996; 32B: 55-62.

28. Klussmann JP, Weissenborn SJ, Weiland U, Dries V, Kolligs J, Jungehuelsing $M$ et al. Prevalence, distribution, and viral load of human papillomavirus 16 DNA in tonsillar carcinomas. Cancer 2001; 92: 2875-84.

29. Miller CS, Johnstone BM. Human papillomavirus as a risk factor for oral squamous cell carcinoma: a meta-analysis, 1982-1997. Oral Surg Oral Med Oral Pathol Oral Radiol Endod 2001; 91: 622-35.

30. Brandwein M, Zeitlin J, Nuovo GJ, et al. HPV detection using "hot start" polymerase chain reaction in patients with oral cancer: a clinicopathological study of 64 patients. (Review). Mod Pathol 1994; 7: 720-7. 